\title{
Upaya Meningkatkan Kemampuan Bekerjasama Anak Usia 5-6 Tahun melalui Metode Bermain Peran di RA (Iraudhatul Athfal) X Kampung Sukarame Desa Cingcin Kecamatan Soreang Kabupaten Bandung
}

\author{
Hasna Nur Zakiyah Darajat* \\ Prodi Pendidikan Guru PAUD, Fakultas Tarbiyah dan Keguruan, Universitas \\ Islam Bandung, Indonesia. \\ "hasnanurzakiyah@gmail.com
}

\begin{abstract}
This research is motivated by the children's ability lack to cooperate on the role playing methods so that the children have difficulty to interract with peers. This is caused because there is not a teacher's specific understanding of the role playing method and there is not the specific approach that directs the child in the role playing method. With the explanation above, the purpose of this study is to improve the results of the ability to cooperate with the early cchildhood of RA Al-Ikhwan Soreang by using the role playing method. The method used in this research is Classroom Action Research with the participants, including RA Al-Ikhwan (Month class) group B with 12 children, 6 male students and 6 female students. It is obtained by using instruments and observations. In this study, the researchers found an increase in each learning that had been carried out. Starting from the pre-cycle results obtained with $47.21 \%$ results up to the second cycle getting $86.80 \%$ results. In the first cycle of action I and II, there was an increase of $13.2 \%$ with the acquisition of $60.41 \%$ in the second cycle there was a significant increase of $86.80 \%$ with the number of students getting satisfactory results of 10 students out of 12 students. From the results of this study, it can be concluded that Improving the Ability to Cooperate Children by Using the Role Playing Method can increase the interaction ability to cooperate with RA Al-Ikhwan Soreang students in Bandung Regency.
\end{abstract}

Keywords: Interaction, Collaboration, and Role Play.

\begin{abstract}
Abstrak. Penelitian ini dilatar belakangi oleh kurangnya kemampuan bekerjasama anak terhadap metode bermain peran sehingga anak kesulitan untuk berinteraksi dengan teman sebaya. Hal ini disebabkan karena tidak adanya pemahaman khusus dari seorang guru mengenai metode bermain peran tersebut serta tidak adanya pendekatan khusus yang mengarahkan anak dalam metode bermain peran. Dengan penjelasan diatas tujuan penelitian ini adalah untuk meningkatkan hasil kemampuan bekerjasama anak usia dini RA AlIkhwan Soreang dengan menggunakan metode bermain peran. Metode yang digunakan dalam penelitian ini adalah Penelitian Tindakan Kelas dengan partisipannya adalah siswa RA Al-Ikhwan (kelas Bulan) kelompok B yang berjumlah 12 orang anak yaitu 6 orang siswa laki-laki dan 6 orang siswa perempuan. Diperoleh dengan menggunakan instrument dan observasi. Pada penelitian ini peneliti menemukan adanya peningkatan dari setiap pembelajaran yang telah dilaksanakan. Dimulai dari hasil pra-siklus diperoleh dengan hasil $47,21 \%$ sampai dengan siklus II memperoleh hasil 86,80\%. Pada siklus 1 tindakan 1 dan 2 terjadi peningkatan sebesar $13,2 \%$ dengan perolehan hasil sebesar $60,41 \%$ pada siklus 2 terjadi peningkatan yang signifikan sebesar $86,80 \%$ dengan jumlah siswa yang mendapat hasil yang memuaskan sebanyak 10 orang siswa dari 12 orang siswa. Dari hasil penelitian ini dapat disimpulkan bahwa Meningkatkan Kemampuan Bekerjasama Anak dengan menggunakan Metode Bermain Peran dapat meningkatkan interaksi kemampuan bekerjasama pada siswa RA Al-Ikhwan Soreang Kabupaten Bandung.
\end{abstract}

Kata Kunci: Interaksi, Bekerjasama, dan Bermain Peran. 


\section{A. Pendahuluan}

Pendidikan anak usia dini memegang peranan sangat penting dalam perkembangan anak karena merupakan pondasi dasar dalam kepribadian anak. Anak yang berusia 0-6 tahun memiliki masa perkembangan kecerdasaan yang sangat pesat sehingga masa ini disebut golden age (masa emas). Masa ini merupakan masa pertama dalam mengembangkan berbagai kegiatan mengenai pengembangan potensi anak. Potensi yang tidak kalah penting bagi kecerdasaan anak yaitu kemampuan bekerja sama dalam perkembangan social emosionalnya dalam bentuk bermain peran. (Masnipal, 2018:2). Menurut Hurlock (Sujiono, 2007) bahwa perkembangan sosial merupakan kemampuan berperilaku sesuai dengan tuntutan sosial dan menjadi individu yang mampu bermasyarakat. Untuk itu anak dapat menjalani kehidupan bermasyarakat dengan 3 proses: a) belajar untuk bertingkah laku dengan cara yang dapat diterima di dalam bermasyarakat, b) belajar bagaimana memainkan peran sosial dalam masyarakat, c) mengembangkan sikap dan tingkah laku terhadap individu lain dan aktivitas sosial bermasyarakat. Dunia berubah semakin lama semakin disadari, kecerdasaan merupakan terminology yang kompleks. Bahwa memiliki pencapaian akademis tak lagi sebagai acuan gambaran tentang kecerdasaan. Namun, tidak demikian dalam pelaksanaan kegiatan pembelajaran melalui metode bermain peran di RA Al-Ikhwan kecamatan Soreang Kabupaten Bandung, metode bermain peran selama ini sangat jarang di lakukan oleh tenaga pendidik di lembaga ini. Mengingat metode ini sangat memakan banyak waktu, dalam hal perencanaan, pelaksanaan, pun memerlukan tempat yang luas agar anak leluasa dalam melaksanakan perannya. Metode ini sangat jarang digunakan, sebab jika pendidik tidak bisa menerapkannya dengan tidak optimal maka pelaksanaanya tidak akan berjalan dengan baik. Padahal metode bermain peran ini memiliki komponen yang sangat baik untuk mengembangkan kemampuan bekerjasama anak terhadap sosial juga emosional anak. Kemampuan anak dalam memahami perspektif orang lain hingga kemampuan memahami situasi sosial penting bagi kemampuan anak dalam memahami duanianya kelak. Kemampuan bekerjasama anak di RA Al-Ikhwan masih rendah karena kurangnya rasa percaya diri dan interaksi antara anak dengan teman sebaya masih rendah. Penelitian ini berfokus pada kemampuan bekerjasama pada anak untuk meningkatkan sosial juga rasa percaya diri pada anak. Dengan kegiatan bermain peran, diharapkan kemampuan bekerja sama pada anak dapat berkembang dengan optimal. Dengan melakukan perkenalan sederhana, kemampuan bekerja sama anak akan berkembangan dengan optimal. Selain itu, anak akan merasa senang karena mampu percaya diri terhadap dirinya ketika bertemu dengan orang lain. Hal tersebut menjadi landasan dasar untuk mengetahui bagaimana kondisi awal kemampuan bekerjasama anak, penerapan kemampuan bekerjasama dan juga bagaimana pengaruh metode bermain peran sebagai kemampuan bekerjasama pada anak. Tujuan dalam penelitian ini untuk mengetahui, kondisi kemampuan bekerjasama pada anak, penerapan yang dilakukan pendidik untuk mengembangkan kemampuan bekerjasama melalui metode bermain peran, dan juga pengaruh metode bermain peran terhadap kemampuan bekerjasama pada anak usia 5-6 tahun. Manfaat penelitian ini adalah untuk mengembangkan ilmu pengetahuan dalam meningkatkan kemampuan bekerjasama pada anak usia 5-6 tahun melalui metode bermain peran di Ra Al-Ikhwan, melalui metode ini diharapkan manafaat baik bagi anak, guru ataupun sekolah. Pendidikan Anak Usia Dini (PAUD)hakikatnya ialah pendidikan yang diselenggarakan dengan tujuan untuk memfasilitiasi prtumbuhan dan erkembangan anak secara menyeluruh atau menekankan pada pengembangan seluruh aspek kepribadian anak. Oleh karena itu, PAUD memberikan kesempatan kepada anak untuk mengembangkan kepribadian dan potensi secara optimal. Kegiatan yang mampu mengembangkan aspek pada perkembangan anak seperti: kognitif, bahasa, sosial, emosi, fisik, dan juga motorik. (Suyadi, dkk: 2013). Kerangka pikir adalah pola pikir penelitian mengenai pelaksanaan penelitian, yang bermula ditemukannya permasalahan di lapangan tentang kemampuan bekerjasama anak yang masih rendah, serta bagaimanan caranya meningkatkan kemampuan bekerjasama anak yang masih rendah itu menjadi meningkat. Dengan ditemukannya permasalahan tersebut, peneliti ingin melakukan suatu upaya untuk membantu permasalahan tersebut. 


\section{B. Landasan Teori}

Kamus Besar Bahasa Indonesia (2005, 707) menjelaskan pengertian mampu adalah kesanggupan atau kecakapan. Sedangkan kemampuan adalah kecakapan, kesanggupan untuk mengerjakan sesuatu yang diwujudkan melalui tindakan untuk meningkatkan produktifitas.Pengertian kemampuan identik dengan pengertian kreativitas telah banyak dikemukakan para ahli berdasarkan pandangan yang berbeda, seperti dinyatakan oleh Supriasi (2006, 87) bahwa, setiap orang yang memiliki kemampuan kreatif dengan tingkat yang berbeda-beda. Tidak ada orang yang tidak memiliki kemampuan atau kreativitas tersebut. Menurut Santosa $(2004,22)$ bekerjasama adalah bentuk interaksi antara anggota kelompok melalui sosial yang berkaitan erat dengan kelompok anggota secara keseluruhan sehingga setiap individu memiliki capaian tujuan antar individu dengan individu yang lainnya. Semua individu memiliki rasa sosial yang tinggi, seseorang yang memiliki kemampuan sosial yang tinggi akan menemukan pencapaian dan tujuan yang sama. Seperti hal nya menurut Carol Seefeldt \& Barbara $(2008,177)$ bahwa kerjasama adalah sebuah gejala untuk mengembangkan kemampuan interaksi antara individu dengan individu yang lain. Bekerjasama juga dapat diartikan sebagai kesanggupan, kecakapan, dan kekuatan untuk berinteraksi antar anggota dalam satu kelompok dalam melakukan kegiatan secara bersama-sama untuk mencapai tujuan bersama. Dengan demikian, indikator kemampuan bekerjasama menurut pedoman pendidikan berorientasi kecakapan Hidup Taman Kanak-Kanak (Depdiksnas, 2006: 17) adalah sebagai berikut: a) Membuat aturan kelompok, b) Menerima aturan kelompok, c) Menghargai kinerja orang lain, d) Menghargai pendapat orang lain, e) Secara bersama-sama menyusun rencana untuk mengerjakan tugas kelompok, f) Membantu orang lain dalam kelompok untuk menyukseskan kerja kelompok. Maka dapat disimpulkan bahwa, kemampuan bekerjasama adalah tindakan antar anggota dengan anggota yang dapat menghasilan kreativitas dengan ketercapaian melalui interaksi antar individu dengan individu yang lain bahwa yang dilandasi dengan berinteraksi. Menurut Yudha M Saputa $(2005,54)$ tujuan bekerjasama untuk anak usia dini yaitu: (a) untuk lebih menyiapkan anak didik dengan berbagai keterampilan baru agar dapat ikut berpartisipasi dalam dunia yang selalu berubah dan terus berkembangan, (b) membentuk kepribadian anak didik agar dapat mengembangkan kemampuan berkomunikasi dan bekerjasama dengan orang lain dalam berbagai situasi sosial, (c) mengajak anak untuk mengembangkan sikap ingin tahu secara aktif karena dalam pembelajaran kerjasama, serta anak Taman Kanak-Kanak tidak hanya menerima pengetahuan dari pendidik begitu saja tetapi anak menyusun pengetahuan yang terus menerus sehingga menempatkan anak sebagai pihak aktif, dan (d) dapat memantapkan interaksi pribadi diantara anak dan diantara pendidik dengan anak didik. hal ini bertujuan untuk membangun suatu proses sosial yang akan membangun pengertian bersama.

Menurut Nurbiana Dhieni (2006, 7.31) mengatakan bahwa metode bermain peran dikatagorikan sebagaimetode dan sikap. Esensi bermain peran ditunjukan untuk membantu individu dalam memahami perannya sendiri dan peran yang dimainkan orang lain sekaligus memahami perasaan oranglain sekaligus berupaya memahami perasaan dan sikap yang mendasarinya. Menurut Ahmadi $(2005,80)$ mengemukakan bahwa metode bermain peran disebut juga "sosiodrama" yaitu suatu cara mengajar yang memberikan kesempatan kepada para anak untuk memdramatisir sikap, tingkah laku, atau penghayatan seseorang, seperti yang dilakukan dalam hubungan sosial sehari-hari dalam masyarakat. Dalam proses bermain peran peserta diminta untuk a) Mengendalikan suatu peranan khusus, apakah sebagai mereka sendiri atau sebagai orang lain, b) Masuk dalam situasi yang bersifat scenario, yang dipilih berdasarkan relevansi dengan pengetahuan yang sedang dipelajari oleh peserta yang sedang dipelajari oleh peserta atau kurikulum, c) Bertindak persis sebagaimana pandangan mereka terhadap orang yang diperankan mereka terhadap orang yang diperankan mereka terhadap orang yang diperankan dalam situasi-situasi tertentu ini, dengan menyepakati untuk bertindak seolah-olah peran-peran tersebut adalah peran-peran mereka sendiri dan bertindak berdasarkan asumsi tersebut dan d) Menggunakan pengalaman-pengalaman pran yag sama pada masa lalu untu mengisi batas yang hilang dalam suatu peran singkat yang ditentukan. Jenis bermain peran terdapat dua jenis, yaitu: a) Bermain peran makro adalah kegiatan dimana anak 
memegang atau menggerak-gerakkan benda-benda berukuran kecil untuk menyusun adegan, seperti anak-anak belajar menjadi sutradara, berukuran kecil seperti rumah-rumahan, kursi sofa mini, tempat tidur mini (seperti bermain boneka Barbie). Biasanya mereka akan menciptakan percakapan sendiri, b) Bermain peran Mikro adalah anak berperan sesungguhnya dan menjadi seseorang atau sesuatu. Saat anak memiliki pengalaman sehari-hari dengan main peran makro (teman sekitar kehidupan nyata), mereka belajar banyak keterampilan seperti anak berperan menjadi seseorang yang mereka inginkan. Bisa mama, papa, tante, polisi, sopir, dan pilot. Saat bermain peran ini biasanya menjadi ajang belajar bagi mereka, baik belajar membaca, berhitung, mempelajari proses/alur dalam mengerjakan sesuatu, mengenal tata tertib/tata cara di suatu tempat, yang semua ada dalam kehidupan kita. Tentu saja kita hanya cukup memberikan informasi sebelum mereka mulai bermain, dan atau lebih baik kalau kita terlibat dalam permainan tersebut agar berbicara dengan memanfaatkan factor fisik, psikologis, neutroligis, semantic, dan linguistic (Suhartono, 2005,44).

\section{Hasil dan Pembahasan}

Berdasarkan hasil penelitian yang telah dilakukan oleh peneliti di RA Al-Ikhwan pada tahap pembahasan, peneliti menggunakan tahapan sesuai dengan Penelitian Tindakan Kelas (PTK) yaitu tahap pra-siklus, siklus I dan siklus II, pada siklus I mempunyai 2 tindakan dan siklus ke 2 mempunyai 2 tindakan. Peneliti akan membahas hasil data penelitian yang telah dilaksanakan, berikut hasil yang telah didapat peneliti setelah melakukan tindakan. Pada awal kemampuan bekerjasama ini anak masih belum mampu mengendalikan emosinya, anak masih sering terjadi konflik bersama temannya ketika anak bermain di dalam kelas maupun di luar kelas, anak masih terlihat individual kemampuan dalam melakukan kerjasama kurang sekali digunakan. Kemampuan bekerjasama anak masih rendah dalam melakukan interaksi, Maka dari itu peneliti merasa perlu melakukan penelitian untuk mengembangkan kemampun bekerjasama terhadap anak 5-6 tahun melalui metode bermain peran. Dari hasil penelitian prasiklus yang telah dilakukan peneliti, masih terdapat siswa yang belum sesuai dengan kriteria yang telah peneliti tetapkan. Masih banyak siswa yang nilai persentasinya berada dibawah ratarata,seperti yang ditampilkan pada table 4.1 bahwa rata-rata yang terdapat pada siswa 47,21 $\%$. Berdasarkan dengan hasil penelitian pada siklus I pertemuan 1 sudah mendapatkan hasil yang muncul pada setiap perkembangan anak, hasil yang didapat oleh siswa yaitu $51 \%$ $58,33 \%$. Pada hasil siklus I pertemuan 1 memiliki hasil rata-rata dari keseluruhan siswa yaitu $55,55 \%$. Berdasarkan dengan hasil penelitian pada siklus I pertemuan 2 sudah mendapatkan hasil yang muncul pada setiap perkembangan anak, dimana rata-ratanya adalah $60,41 \%$ hal ini terlihat pada siklus I pertemuan 1 yang sudah mendapatkan kategori yang sudah cukup optimal dibandingkan dengan hasil sebelumnya. Dari hasil Siklus II pertemuan 1 ini peneliti melihat adanya peningkatan kualitas terhadap kemampuan bekerjasama secara menyeluruh, dimana rata-rata pada hasil penelitiannya adalah $86,80 \%$, hal ini menunjukan bahwa adanya dominasi antar siswa yang mempunyai hasil terdapat pada hasil nya yang sudah melampaui hasil pada penelitian. Berdasarkan hasil yang terlihat pada tabel 4.5 peneliti menemukan bahwa kemampuan bekerjasama pada siswa dalam melaksanakan metode bermain peran mengalami peningkatan persentase setiap siklus dan pertemuannya, pada pra-siklus persentase yang didapat oleh siswa sebesar (47.21\%). Pada siklus I pertemuan 1 persentase keseluruhan siswa sebesar $(55,55 \%)$, dan terjadi pula peningkatan pada siklus I pertemuan 2 sebanyak $(60,41 \%)$, karena dianggap masih kurang oleh peneliti maka peneliti melanjutkan pada siklus II pertemuan 1 terjadi peningkatan pada pertemuan ini dari hasil persentasi seluruh siswa sebesar $(86,80 \%)$. Dengan demikian, proses kemampuan bekerjasama yang diberikan pada anak dapat tercapai sesuai dengan tujuan pada penelitian ini.

\section{Kesimpulan}

Berdasarkan hasil penelitian yang dilakukan oleh peneliti dari observasi awal sampai dengan siklus 2, peneliti menyimpulkan: 1) Kondisi awal kemampuan bekerjasama anak usia 5-6 tahun di RA Al-Ikhwan sudah sesuai dengan teori, namun belum berjalan dengan optinal. 
Pelaksanaan pada penelitian ini adalah dimana anak mulai memiliki rasa percaya diri terhadap diri sendri dengan teman sebauaya atau lingkungannya. Dengan mengembangkan metode bermain peran terlihat interaksi anak yang signifikan, sesuai dengan teori bahwa metode bermain peran dapat meningkatkan kemampuan bekerjasama pada anak. 2) pelaksanaan pada penelitian ini sudah adanya rasa percaya diri terhadap anak sehingga anak mampu berinteraksi dengan teman sebaya. Dari hasil prasiklus anak, bahwa kemampuan bekerjasama di RA AlIkhwan masih memiliki kualifikasi yang Belum Berkembang (BB) yaitu dengan hasil rata-rata dari keseluruhan siswa $47,21 \%$, pada siklus I pertemuan I terjadi peningkatan pada anak dengan kualifikasi Mulai Berkembang (MB) dengan hasil rata-rata 55,55\%, pada tindangan selanjutnya yaitu Siklus I pertemuan 2 bahwa kemampuan bekerjasama anak meningkat dengan kualifikasi Berkembang Sesuai Harapan (BSH) dengan hasil rata-rata 60,41\%. Pada siklus II mengalami peningkatan yang signifikan sebesar $26,39 \%$ pada siklus ini memiliki kualifikasi hasil sebesar $86,80 \%$, kualifikasi tersebut sudah mencapai indikator keberhasilan dengan memperoleh kriteria Berkembang Sangat Baik (BSB) adalah anak mendapatkan skor nilai sebanyak 4 dari pada indikator yang sudah ditentukan. 3) Pengaruh bermain peran pada penelitian ini adalah anak merasa senang ketika mereka Bermain peran dalam penelitian ini adalah bermain tangkap binatang peliharaan anak memerankan dirinya sebagai binatang , menjadi kucing, anjing, bebek, dan monyet. Kelompok yang dipecah menjadi 4 yaitu, kucing terdiri dari 4 orang, anjing terdiri dari 2 orang, bebek terdiri dari 4 orang dan monyet terdiri dari 2 orang. Langkah yang pertama dalam permainan ini adalah, pendidik memberikan penjelasan tentang keadaan sekitar lalu pada masing-masing kelompok di berikan tempat masing-masing sebagai rumah dari pada kelompok-kelompok tersebut. Langkah kedua, pendidik memberikan arahan bagaimana cara bermain peran yang akan dilakukan tersebut. Langkah ketiga pendidik memberikan aba-aba kepada siswa agar siswa mulai memainkan perannya dengan menangkap pada masing-masing buruannya. Langkah keempat, pendidik memberikan peraturan pada permainan dan memberikan penjelasan cara bermain secara perlahan, dan berulang-ulang. Anak melakukan kegiatan bermain di dalam kelas dan di luar kelas.

\section{Daftar Pustaka}

[1] Masnipal, 2018 Menjadi Guru Paud Profesional, Bandung: PT. Remaja Rosda Karya

[2] Hurlock, Elizabeth B, 1987 Perkembangan Anak Jilid 1 (Alih Bahasa Meitasari.

[3] Tjandrasa dan Muslichah Zarkasih). Jakarta: Erlangga.

[4] Seefeldt, Carol \& Barbara, 2008 Pendidikan Anak Usia Dini. Jakarta: PT Macanan Jaya Cemerlang.

[5] Depdikbud, 2008 Kurikulum Hasil Belajar Pendidikan Anak Usia Dini, Jakarta: Balitbang Kurikulum.

[6] Depdikbud, 2005 Kurikulum Hasil Belajar Pendidikan Anak Usia Dini, Jakarta: Balitbang Kurikulum.

[7] Suyanto, 2007 Pedoman Umum Menyelenggarakan Pendidikan Inklusif : Direktorat Jendral Mendikdasmen Direktorat Pembinaan Sekolah Luar Biasa

[8] Yudha M. Saputra \& Rudyanto, 2005 Pembelajaran Kooperatif Meningkatkan Keterampilan Anak Tk, Jakarta: Departemen Pendidikan Nasional, Direktorat Jendral Pendidikan Tinggi, Direktorat Pembinaan Pendidikan Tenaga Kependidikan, dan Ketenagaan Perguruan Tinggi 